\title{
RELATIVE STANDING OF ROE AND ROCE IN EFFECTIVE LIQUIDITY MANAGEMENT: EVIDENCE FROM BANGLADESHI COMMERCIAL BANKS
}

\author{
Dr. Nazneen Jahan Chaudhury \\ Associate Professor \\ Department of Business Administration \\ International Islamic University Chittagong, Chattogram, Bangladesh \\ E-mail: nazneenchy@yahoo.com \\ iDhttps://orcid.org/0000-0002-1172-3576
}

Received: September 23, 2021 Accepted: November 12, $2021 \quad$ Online Published: November 27, 2021

DOI: 10.46281/amfbr.v6i1.1459

URL: https://doi.org/10.46281/amfbr.v6i1.1459

\begin{abstract}
This study has been designed for examining the effectiveness of liquidity management through the relative standing of ROE and ROCE of Nationalized Commercial Banks in Bangladesh for the duration of 2008-2018. Six NCBs are selected purposively as sample. The study relies on a balanced panel data set of 66 observations which are gathered from the annual reports of banks and analyzed by random effects regression model. However, the research only examined a few variables. The empirical results reveal that the selected NCBs have been portraying better standing in case of ROE than ROCE in effective liquidity management. The value of $R^{2}$ of $R O E$ is $75.25 \%$; it signifies that the explanatory measures could clarify $75.25 \%$ of the variations in ROE. Among the liquidity measures, Assets/Shareholders Equity has highly significant negative effect; Tier 1 Capital/Risk Weighted Assets has highly significant positive effect; Deposits/Assets have some significant positive and Bank Size in terms of Deposits has some significant negative effect on ROE of the selected NCBs.
\end{abstract}

Keywords: Bangladesh, Commercial Bank, Effective Liquidity Management, ROE, ROCE.

JEL Classification Codes: E44, G14, G21, O16.

\section{PRELUDE}

Banking system is one of the major components of financial system for ensuring its continued existence. According to Wilner (2000), efficient banking system acts as a means for the accumulation of deposit funds and investing those funds in a productive manner. Without effective liquidity management, banks with intense foundation and bright future may not be profitable (Jose et al., 1996). Therefore liquidity management involves the strategic administration of inflows and outflows of banks' funds that will concurrently maintain liquidity, profitability and solvency of banks. Agbada and Osuji (2013) articulated that with a view to achieving these conflicting objectives, liquidity management requires to be efficient in the 
circulation of liquidity compatible with a preferred level of cash without twisting the profitability and functions of the bank.

\section{Banking structure of Bangladesh}

Bangladesh has an assorted banking sector of 60 scheduled banks consisting of 06 Nationalized Commercial Banks, 03 Specialized Banks, 42 Private Commercial Banks and 09 Foreign Commercial Banks. Out of 42 Private Commercial Banks, 32 banks are interest based whereas 8 are interest free (www.bb.org.bd/fnansys/bankfi.php).

\section{LITERATURE REVIEW}

Basel Committee on Banking Supervision (2008) explained that bank's sustainability is dependent on the liquidity position as it measures the role of bank in maintaining cash flow. According to Central Bank of Barbados (2008), liquidity problem may usually influence a bank's profits and capital and exceptional circumstance, due to liquidity problem a solvent bank may become insolvent. Jenkinson (2008) found that liquidity problem simultaneously affects both the performance and reputation of a bank. According to Aspachs et al. (2005), banks can use three methods to indemnify against liquidity risks. Such as (i) seizing bumper of liquid assets (ii) relying on interbank market (iii) relying on central bank-a lender of last resort.

Hirigoyen (1985) agreed that low liquidity leads to low profitability. Chandra (2001) claimed that usually high liquidity acts as a signal of financial strength. AssafNeto (2003) argued that both high and low liquidity are undesirable. According to Goddard et al. (2004), holding liquidity causes an opportunity cost and thereby having a negative consequence on profit making ability of banks. Gup and Kolari (2004) claimed that bank management should extend a liquidity plan that makes a balance between risks and returns. Koch (1992); Sufian and Chong (2008) believed that as maintenance of liquidity bears both risk and return, a trade-off between liquidity and profit base can minimize the conflict.

Repullo (2003) found that liquidity management depends on hybrids of theories that are typically employed to obtain optimality. Considering Shiftability theory, Dodds (1982) suggested that assets must meet three conditions-"shiftability, marketability or transferability" in order to ensure convertibility of the assets. Based on Anticipated Income theory, Nzotta (1997) identified two fundamental factors-earning capability and creditworthiness of a borrower which can be regarded as the undertaking for assuring sufficient liquidity. According to Liability Management theory, Emmanuel (1997) suggested that the central bank or sister banks can come forward to lend money if other banks urgently require funds. He also propagated a very conservative outlook when he asserted that the banks do not lend money for long term, due to the long payback period. Hence Commercial Loan theory is only applicable for short period, selfliquidating loans.

Agbada and Osuji (2013) experienced that the soundness of banks can be enhanced by efficient liquidity management. According to Kurawa and Abubakar (2014); Obida and Owolabi (2012), liquidity management measures the growth and financial performance of a bank. As per Nwankwo (1991), liquidity management requires assessing liquidity needs and meeting up those needs at all times without incurring any significant costs. It is asserted that adequate liquidity at normal market interest rate is crucial for both large and small banks to meet all types of liabilities. It is also said that adequate liquidity may help a bank to face three kinds of liquidity risks: (i) risk of funding (ii) default risk (iii) risk of failure to honor maturity obligations of customers. 
According to Lartey et al. (2013), there is a very insignificant but positive association between optimum levels of liquidity and profit base. According to Osborne et al. (2012), the association between liquidity and profit base becomes more positive in the distress of banking sector. Arif and Anees (2012); Datta et al. (2011); Adebayo et al. (2011) observed that profit base is significantly influenced by liquidity in the form of deposits. Rauch et al. (2010) found that profit base is negatively associated with liquidity. Other things held constant, adequate liquidity can improve profit base of banks (Bernanke, 2008). Flannery and Rangan (2008) asserted that due to sudden shock or regulatory requirements, if liquidity of banks exceeds their optimum level reduces profit base only. Jahangir et al. (2007) argued that loan deposit ratio works as an important determinant of banks' profitability. Hossain (2000) indicated that high percentage of fixed to total deposits influence the profitability performance of NCBs.

Lucy et al. (2018) found that liquidity has significant positive effect on ROCE. Agbada and Osuji (2013) explored that adequate capital is a must for maximizing ROCE. Raza, Farhan, and Akram (2011) affirmed that ROCE is one of the major measures to measure profitability. Alshatti (2015) recommended that quick ratio and investment ratio are positively associated with ROE whereas capital ratio and liquid asset ratios are negatively associated with ROE. According to Bassey (2015), cash ratio, loan to deposit ratio, current ratio, loan to asset ratio and liquid ratio are significantly related with ROE. Olarewaju and Adeyemi (2015) stated that there is no causal relationship between loan deposit ratio and ROE. According to Abdullah and Jahan (2014), all other things held constant, the more liquid bank tends to have lower ROE. Tabari, Ahmadi, and Emami (2013) acknowledge that ROE is one of the substitutes to measure profit base of a bank. Ramadan et al. (2011) showed that there is an association between ROE and the efficacy of credit management. According to Ahmed et al. (2006), in order to fortify the economic conditions of a country, NCBs must improve their performance evaluation metrics such as NPL, ROA and ROE. Siddique (2004) recognized that NPL is one of the outcomes of poor bank fund management.

In the above sections the researcher has conducted an extensive review of literatures over banks' liquidity management nationally and internationally. It is found that maximum studies have been conducted over management of liquidity and banking performance, liquidityprofitability relationship, and role of liquidity on banks' profitability. However, relative standing of profitability measures in effective liquidity management in Bangladesh remains an unexplored area. Hence, the present study has been carried out to evaluate the relative standing of ROE and ROCE of NCBs in efficient liquidity management.

\section{OBJECTIVES OF THE STUDY}

The key objective of this study is to analyze the relative prominence of ROE and ROCE in effective liquidity management of NCBs. This objective basically attempts:

- To evaluate the descriptive features of both liquidity and profitability measures of respective banks;

- To analyze the liquidity measures that influence both the ROE and ROCE;

- To measure the association between liquidity measures and selected profitability measures;

- To appraise the comparative position of ROE and ROCE in ensuring effective liquidity management of selected NCBs; 


\section{THEORETICAL FRAMEWORK}

\section{Independent Variables (Liquidity Indicators)}

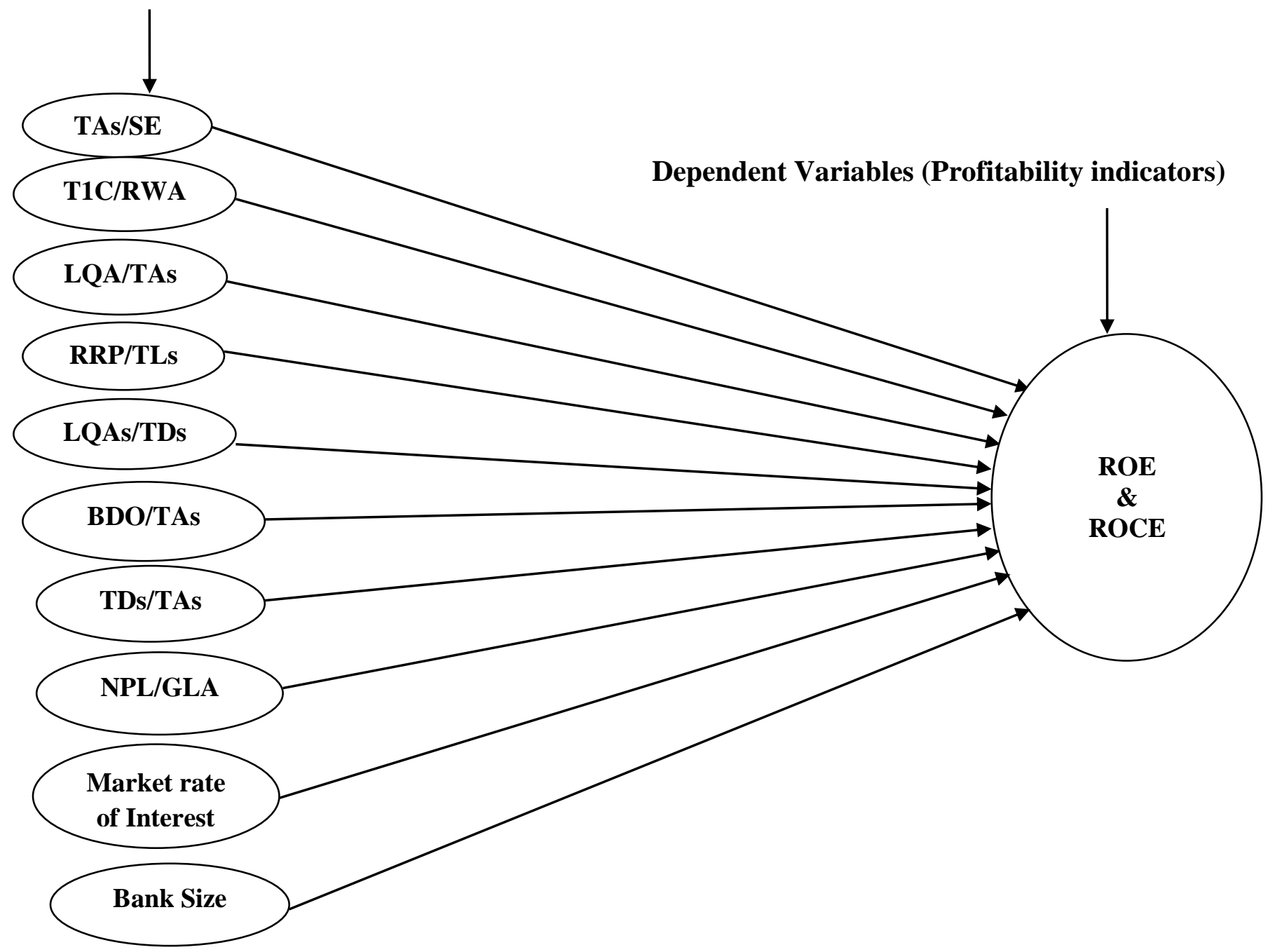

Figure 1. Theoretical Framework

\section{Research Design}

\section{METHODOLOGY OF THE STUDY}

The study is descriptive as well as analytical in nature. It is descriptive as it demonstrated the effectiveness of liquidity management of NCBs in Bangladesh through the measures of relative standing of its ROE and ROCE. This study is analytical in the sense that it carried out a panel data analysis for testing hypothesis and interpreting relationship by analyzing available information. Basically, the study intends to provide an appropriate strategy for the effective liquidity management of NCBs in Bangladesh.

\section{Hypotheses of the Study}

$H_{01}$ : There is no statistically significant relationship between liquidity and ROE of NCBs $H_{11}$ : There is a statistically significant relationship between liquidity and ROE of NCBs $H_{02}$ : There is no statistically significant relationship between liquidity and ROCE of NCBs 
$H_{12}$ : There is a statistically significant relationship between liquidity and ROCE of NCBs

\section{Specification of the Model}

Model 1: ROE $=\mathrm{A}+\beta_{1}(\mathrm{TAs} / \mathrm{SE})+\beta_{2}(\mathrm{~T} 1 \mathrm{C} / \mathrm{RWA})+\beta_{3}(\mathrm{LQA} / \mathrm{TAs})+\beta_{4}(\mathrm{RRP} / \mathrm{TLs})+\beta_{5}$ $(\mathrm{LQA} / \mathrm{TDs})+\beta_{6}(\mathrm{BDO} / \mathrm{TAs})+\beta_{7}(\mathrm{TDs} / \mathrm{TAs})+\beta_{8}(\mathrm{NPL} / \mathrm{GLA})+\beta_{9}(\mathrm{MRI})+\beta_{10}(\mathrm{BSZ})+\mathrm{e}$

Model 2: ROCE $=\mathrm{A}+\beta_{1}(\mathrm{TAs} / \mathrm{SE})+\beta_{2}(\mathrm{~T} 1 \mathrm{C} / \mathrm{RWA})+\beta_{3}(\mathrm{LQA} / \mathrm{TAs})+\beta_{4}(\mathrm{RRP} / \mathrm{TLs})+\beta_{5}$ $(\mathrm{LQA} / \mathrm{TDs})+\beta_{6}(\mathrm{BDO} / \mathrm{TAs})+\beta_{7}(\mathrm{TDs} / \mathrm{TAs})+\beta_{8}(\mathrm{NPL} / \mathrm{GLA})+\beta_{9}(\mathrm{MRI})+\beta_{10}(\mathrm{BSZ})+\mathrm{e}$

Where, ROE and ROCE are the dependent variables, $\mathrm{A}$ is the constant term, $\beta$ 's measures the coefficient of explanatory variables, variables in the parenthesis are the explanatory variables and 'e' denotes the stochastic disturbance term.

Table 1. Elucidation of dependent and independent variables and their replacements

\begin{tabular}{|l|l|c|}
\hline \multicolumn{1}{|c|}{ Variables } & \multicolumn{2}{c|}{ Eormula/ Definition } \\
\hline Dependent Variables & \multicolumn{2}{|c|}{} \\
\hline ROE & Net income/ Shareholders equity & $\%$ \\
\hline ROCE & EBIT/(Total assets-current liabilities) & $\%$ \\
\hline Independent Variables & \multicolumn{2}{|c|}{} \\
\hline TAs/SE & Total assets/Shareholders equity & $\%$ \\
\hline TIC/RWA & Tier 1 capital/Risk weighted assets & $\%$ \\
\hline LQA/TAs & Liquid asset/Total assets & $\%$ \\
\hline RRP/TLs & Reverse Repo Purchase/Total liabilities & $\%$ \\
\hline LQA/TD & Liquid asset/Total deposits & $\%$ \\
\hline BDO/TAs & Balance due other banks/Total assets & $\%$ \\
\hline TDs/TAs & Total deposits/Total assets & \% \\
\hline NPL/GLA & Nonperforming loan/Gross loan \& advances & $\begin{array}{c}\text { Natural logarithm } \\
\text { of total deposit }\end{array}$ \\
\hline MRI & Market rate of interest & Bank size in terms of total deposits \\
\hline BSZ & &
\end{tabular}

Source: Compiled by the researcher from the annual reports of banks

\section{Choice of Population, Sample Size and Sampling method}

According to Bangladesh Bank, the no. of scheduled NCBs in Bangladesh is 06. Accordingly the researcher opted for $06 \mathrm{NCBs}$ purposively.

\section{Collection and Analysis of Data}

The study is mainly dependent on secondary data that have been gathered from yearly published information of selected NCBs. This balanced panel data sets of 66 observations throughout the period of 2008-2018 have been evaluated by some descriptive statistics, pairwise correlation, ratio analysis and ultimately, random effects regression model. 
FINDINGS AND DISCUSSIONS Analysis of Features of Liquidity Indicators and Profitability Indicators of selected NCBs

Table 2. Descriptive Analysis of related variables

\begin{tabular}{|c|c|c|c|c|c|c|c|c|c|c|c|c|}
\hline $\begin{array}{c}\text { Measu } \\
\text { res }\end{array}$ & ROE & $\begin{array}{c}\text { ROC } \\
\text { E }\end{array}$ & $\begin{array}{c}\text { TAs } \\
/ \\
\text { SE }\end{array}$ & $\begin{array}{c}\text { TIC } \\
/ \\
\text { RW } \\
\text { A }\end{array}$ & $\begin{array}{r}\text { LQ } \\
\text { A/ } \\
\text { TAs }\end{array}$ & $\begin{array}{c}\text { RR } \\
\text { P/ } \\
\text { TLs }\end{array}$ & $\begin{array}{c}\text { LQ } \\
\text { A/ } \\
\text { TD }\end{array}$ & $\begin{array}{c}\text { BD } \\
\text { O/ } \\
\text { TAs }\end{array}$ & $\begin{array}{l}\text { TDs } \\
/ \\
\text { TAs }\end{array}$ & $\begin{array}{l}\text { NPL/ } \\
\text { GLA }\end{array}$ & MRI & BSZ \\
\hline Mean & 0.18 & 1.99 & $\begin{array}{c}17.4 \\
4\end{array}$ & 5.14 & 9.22 & 5.30 & $\begin{array}{c}12.7 \\
4\end{array}$ & 1.20 & $\begin{array}{c}80.3 \\
2\end{array}$ & 18.90 & $\begin{array}{c}11.7 \\
8\end{array}$ & 5.54 \\
\hline Range & $\begin{array}{c}301.1 \\
8\end{array}$ & 19.77 & $\begin{array}{c}68.6 \\
0\end{array}$ & $\begin{array}{c}30.9 \\
5\end{array}$ & $\begin{array}{c}12.6 \\
6\end{array}$ & 5.98 & $\begin{array}{c}18.8 \\
7\end{array}$ & 5.44 & $\begin{array}{c}15.5 \\
2\end{array}$ & 29.98 & 4.19 & 1.19 \\
\hline Max. & 41.28 & 9.85 & $\begin{array}{c}52.8 \\
7\end{array}$ & 9.78 & $\begin{array}{c}17.2 \\
5\end{array}$ & 9.64 & $\begin{array}{c}26.1 \\
7\end{array}$ & 5.44 & $\begin{array}{c}85.9 \\
3\end{array}$ & 35.28 & $\begin{array}{c}13.7 \\
5\end{array}$ & 6.04 \\
\hline Min. & $\begin{array}{c}- \\
259.9 \\
0\end{array}$ & -9.92 & $\begin{array}{c}- \\
15.7 \\
3\end{array}$ & $\begin{array}{c}- \\
21.1 \\
7\end{array}$ & 4.59 & 3.66 & 7.30 & 0.00 & $\begin{array}{c}70.4 \\
1\end{array}$ & 5.30 & 9.56 & 4.85 \\
\hline $\begin{array}{l}\text { Std. } \\
\text { Dev. }\end{array}$ & 43.70 & 2.83 & $\begin{array}{c}10.2 \\
8\end{array}$ & 5.52 & 2.87 & 1.08 & 4.27 & 1.29 & 3.78 & 7.60 & 1.32 & 0.30 \\
\hline $\mathrm{CV}$ & $\begin{array}{c}247.4 \\
5\end{array}$ & 1.42 & 0.59 & 1.07 & 0.31 & 0.20 & 0.34 & 1.08 & 0.05 & 0.40 & 0.11 & 0.05 \\
\hline
\end{tabular}

Notes: i) Data have been compiled by the researcher

ii) Analysis Mode: SPSS (version 24.0)

From the above analysis the study has found that the selected banks have maintained the highest average liquidity ratio i.e $80.32 \%$ in terms of TDs/TAs which is authenticated by standard deviation of $3.78 \%$, and range of $15.52 \%$; and the lowest average liquidity ratio i.e $1.20 \%$ in terms BDO/TAs which is authenticated by standard deviation of $1.29 \%$, and range of $5.44 \%$ during study periods. Between these two liquidity ratios, TDs/TAs indicates minimum risk in terms of $\mathrm{CV}$ i.e $0.05 \%$. It has been observed that average rate of profitability in terms of ROE and ROCE is $0.18 \%$ and $1.99 \%$ respectively. Between two profitability indicators, the maximum \& minimum ratio of ROE has shown maximum fluctuation during the study periods. This situation is authenticated by standard deviation of $43.70 \%$, and range of $301.18 \%$. It indicates that selected banks are exposed to more risk in generating profit in terms of ROE than ROCE while managing liquidity. This signifies that selected NCBs should give due consideration to ROE particularly in making profit while constructing liquidity management policies \& implementing thereof.

\section{Regression Analytical Tests Normality Test}


Table 3. Shapiro-Wilk Test for Normality

\begin{tabular}{|c|c|}
\hline Variable & p value \\
\hline ROE/ROCE & $0.12 / 0.08$ \\
\hline TAs/SE & 0.08 \\
\hline TIC/RWA & 0.43 \\
\hline LQA/TAs & 0.06 \\
\hline RRP/TLs & 0.20 \\
\hline LQA/TD & 0.22 \\
\hline BDO/TAs & 0.11 \\
\hline TDs/TAs & 0.06 \\
\hline NPL/GLA & 0.58 \\
\hline MRI & 0.18 \\
\hline BSZ & 0.21 \\
\hline
\end{tabular}

Notes: i) Data have been compiled by the researcher ii) Analysis Mode: STATA (version 12.0)

From table 3 , it is clear that the data used in this study is normally distributed as p value $>0.05$.

Multicollinearity Test

Table 4. Analysis of Correlation between Liquidity indicators and Profit base of selected NCBs

\begin{tabular}{|c|c|c|c|c|c|c|c|c|c|c|c|c|}
\hline & ROE & $\begin{array}{l}\text { RO } \\
\text { CE }\end{array}$ & $\begin{array}{c}\text { TAs/ } \\
\text { SE }\end{array}$ & $\begin{array}{r}\text { TIC/ } \\
\text { RWA }\end{array}$ & $\begin{array}{c}\text { LQA/ } \\
\text { TAs }\end{array}$ & $\begin{array}{c}\text { RRP/ } \\
\text { TLs }\end{array}$ & $\begin{array}{c}\text { LQA/ } \\
\text { TD }\end{array}$ & $\begin{array}{c}\text { BDO/ } \\
\text { TAs }\end{array}$ & $\begin{array}{l}\text { TDs/ } \\
\text { TAs }\end{array}$ & $\begin{array}{l}\text { NPL/ } \\
\text { GLA }\end{array}$ & MRI & BSZ \\
\hline ROE & 1 & & & & & & & & & & & \\
\hline$\underset{\mathbf{E}}{\mathbf{R O C}}$ & .101 & 1 & & & & & & & & & & \\
\hline $\begin{array}{c}\text { TAs/ } \\
\text { SE }\end{array}$ & $\begin{array}{c}- \\
.572^{* *}\end{array}$ & 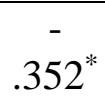 & 1 & & & & & & & & & \\
\hline $\begin{array}{l}\text { TIC/ } \\
\text { RWA }\end{array}$ & $.378^{*}$ & -.178 & $.312^{*}$ & 1 & & & & & & & & \\
\hline $\begin{array}{c}\text { LQA/ } \\
\text { TAs }\end{array}$ & .037 & -.165 & 160 & . 157. & 1 & & & & & & & \\
\hline $\begin{array}{c}\text { RRP/ } \\
\text { TLs }\end{array}$ & .079 & -.173 & -.055 & .136 & $.356^{*}$ & 1 & & & & & & \\
\hline $\begin{array}{c}\text { LQA/ } \\
\text { TD }\end{array}$ & .099 & -.077 & .098 & .268 & $.788^{* *}$ & .226 & 1 & & & & & \\
\hline $\begin{array}{c}\text { BDO/ } \\
\text { TAs }\end{array}$ & .065 & .237 & $\begin{array}{c}- \\
.394^{*}\end{array}$ & ${ }^{-} 483^{* *}$ & .105 & .043 & -.023 & 1 & & & & \\
\hline $\begin{array}{l}\text { TDs/ } \\
\text { TAs }\end{array}$ & .126 & -.192 & .006 & -.073 & $.435^{* *}$ & .235 & .196 & $.347^{*}$ & 1 & & & \\
\hline NPL/ & -.258 & -.144 & .144 & -.190 & .038 & . 205 & -.004 & -.113 & .017 & 1 & & \\
\hline
\end{tabular}




\begin{tabular}{|c|c|c|c|c|c|c|c|c|c|c|c|c|}
\hline GLA & & & & & & & & & & & & \\
\hline MRI & -.237 & .201 & .057 & -.219 & $-.348^{*}$ & -.181 & $.481^{* *}$ & .182 & -.212 & -.067 & 1 & \\
\hline BSZ & -.047 & $\begin{array}{c}- \\
.464^{*}\end{array}$ & .287 & $.488^{* *}$ & .184 & $.409^{* *}$ & .222 & $.490^{-}$ & .168 & $.333^{*}$ & $.324^{*}$ & 1 \\
\hline
\end{tabular}

Notes: i) Data have been compiled by the researcher

ii) Analysis mode: SPSS (version 24.0)

iii) ${ }^{*}$ Correlation is significant at the $5 \%$ level

** Correlation is significant at the $1 \%$ level

From table 04, it is observed that as the correlation between the variables is below the maximum limit of 0.80 , so the variables are beyond multicollinearity problem which is supported by Kennedy (2008).

Another important method of identifying multicollinearity is the Variance Inflation Factor (VIF). According to Gujarati and Sangeetha (2008), if the VIF value exceeds 10, the variable is considered to be highly collinear. The VIF test result for all the explanatory variables are shown in appendix 1A where there is no existence of multicollinearity problem as the VIF value of the variables is less than 10 .

\section{Heteroskedasticity Test}

White's heteroskedasticity test is applied to measure the difficulty of heteroskedasticity in a linear regression model (Gujarati, 1995). The outcomes of both analysis indicate that there is no evidence for the existence of heteroskedasticity, as the calculated values $44.00<$ the critical value 79.49 as shown in appendix $1 \mathrm{~B}$ and $1 \mathrm{C}$.

\section{Test of Autocorrelation}

One of the most popular tests for the detection of autocorrelation is Wooldridge (2002) statistic which signifies that there is no autocorrelation, as presented below:

Table 5. Wooldridge Test for Autocorrelation

\begin{tabular}{|l|l|}
\hline \multicolumn{1}{|c|}{ ROE } & \multicolumn{1}{c|}{ ROCE } \\
\hline Ho: no first - order autocorrelation & Ho: no first - order autocorrelation \\
$\mathrm{F}(1,3)=4.733$ & $\mathrm{~F}(1,3)=1.736$ \\
Prob $>\mathrm{F}=0.1178$ & Prob $>\mathrm{F}=0.2792$ \\
\hline
\end{tabular}

Notes: i) Data have been compiled by researcher

ii) Analysis mode: STATA (version 12.0)

\section{Hausman Specification Test}

A Hausman Test (1978) has been applied to measure the appropriateness of Random versus Fixed effects model which is reported in appendix 1D and 1E. After running the Hausman test, both Prob>chi2 value of ROE and ROCE are 0.3881 and .8494 respectively, which are greater 
than 0.05. Therefore the Random Effects model is statistically appropriate for both the model of the study.

Random Effect (RE) tests on Model 1 (ROE) and Model 2 (ROCE)

Table 6. Position of ROE and ROCE in the Effectiveness of Liquidity Management

\begin{tabular}{|l|c|c|}
\hline \multicolumn{1}{|c|}{ Variables } & Model 1 (ROE) & Model 2 (ROCE) \\
\hline Constant & 79.3944 & $23.9873^{*}$ \\
\hline TAs/SE & $-3.2398^{* * *}$ & -.0787 \\
\hline TIC/RWA & $6.0589^{* * *}$ & .0709 \\
\hline LQA/TAs & .1159 & -.1708 \\
\hline RRP/TLs & -.4326 & .0154 \\
\hline LQA/TD & -.5235 & .1532 \\
\hline BDO/TAs & -3.5083 & -.0177 \\
\hline TDs/TAs & $3.1273^{* *}$ & -.032 \\
\hline NPL/GLA & .5269 & .0333 \\
\hline MRI & -2.5484 & .3275 \\
\hline BSZ & $-49.2252^{* *}$ & $-4.2098^{*}$ \\
\hline F & $\mathbf{1 0 . 0 3}$ & $\mathbf{1 . 2 7 1}$ \\
\hline $\mathbf{R}^{\mathbf{2}}$ & $\mathbf{. 7 5 2 5}$ & $\mathbf{. 2 4 9 3}$ \\
\hline Adjusted R & $\mathbf{. 5 9 2 5}$ & $\mathbf{. 0 5 3 0}$ \\
\hline $\begin{array}{l}\text { No. of } \\
\text { observations }\end{array}$ & $\mathbf{6 6}$ & $\mathbf{6 6}$ \\
\hline
\end{tabular}

Notes: i) Data have been compiled by researcher

ii) Analysis mode: STATA (version 12.0)

iii) Standard errors in parentheses ${ }^{*} p<0.10,{ }^{* *} p<0.05,{ }^{* * *} p<0.01$

From RE regression Model 1, it has been observed that the variables TAs/SE \& TIC/RWA are significant at $1 \%$ level and TDs/TAs \& BSZ at 5\% level. The rest of the variables are found insignificant. The value of $\mathrm{R}^{2}$ is $75.25 \%$; it signifies that the explanatory variables could clarify $75.25 \%$ of the variations in ROE. F value of statistics is also found significant. F value of statistics is also found significant.

From RE regression Model 2, it has been observed that almost all the explanatory variables are found insignificant even $\mathrm{BSZ}$ as it is significant at $10 \%$ level. The value of $\mathrm{R}^{2}$ is $24.93 \%$; it signifies that the explanatory variables could clarify only $24.93 \%$ of the variations in ROCE. F value of statistics is also found insignificant.

These imply that standing of ROE compared to ROCE is more significant in the effectiveness of liquidity management of selected NCBs in Bangladesh. Accordingly, in case of Model 1 the null hypothesis is rejected and alternative hypothesis is accepted. That is, there is a statistically significant association between ROE and liquidity of NCBs. On the other hand, the null hypothesis of Model 2 is accepted indicating that there is no statistically significant association between ROCE and liquidity of NCBs. 


\section{CONCLUSION AND RECOMMENDATIONS}

The study is attempted to figure out the relative standing of ROE and ROCE in the effectiveness of liquidity management of NCBs in Bangladesh. It is found that ROE represents better standing than ROCE in case of effective liquidity management. The ROE is mainly influenced by TAs/SE, TIC/RWA, TDs/TAs and BSZ liquidity measures. Among the explanatory measures, TAs/SE has highly significant negative and TIC/RWA has highly significant positive effect on ROE; TDs/TAs has some significant positive and BSZ has some significant negative effect on ROE of the selected NCBs.

The conclusion recommends that NCBs that can increase its core capital will act as a defender in protecting consumers against unexpected losses and to exude financial strength. Papa (2012) said that banks can simply drive up ROE by holding relatively higher levels of Tier 1 capital. According to Abugamea (2018); Ramadan et al. (2011), profitability in terms of ROE tends to be associated with well capitalized banks. Abugamea (2018) also asserted that ROE is inversely related to deposits which is supported by the ratio BSZ in terms of total deposits. But higher deposits to assets ratio is linked with improved financial sufficiency, as deposits are the stable sources of fund for funding assets (Mwangi et al., 2015). There is a common phenomenon that banks' profitability is extensively affected by its higher total assets provided the assets are financed by stock rather than debt. Ramadan et al. (2011) showed that there is an association between ROE and the efficacy of credit management.

Based on the empirical assessment, the researcher recommends that NCBs should accept a more professional liquidity management strategy to insure such conflicting objectives of banksliquidity, profitability and solvency. Agbada and Osuji (2013) articulated that with a view to achieving these conflicting objectives, liquidity management requires to be efficient in the circulation of liquidity compatible with a preferred level of cash without twisting the profitability and functions of the bank. Without effective liquidity management, banks with intense foundation and bright future may not be profitable (Jose et al., 1996).

\section{LIMITATIONS OF THE STUDY}

The study has considered a limited no. of variables and only four selected NCBs in Bangladesh as sample. Therefore the size of the sample might be increased for measuring the actual effect of exogenous variables on the dependent variable. New research could be suggested for measuring the relative standing of other profitability measures not only on NCBs but also on other banking structure in Bangladesh to appraise whether the liquidity is effectively managed or not.

\section{REFERENCES}

Abdullah, M. N., \& Jahan, N. (2014). The impact of Liquidity on Profitability in banking sector of Bangladesh: A case of Chittagong Stock Exchange. International Journal of Economic and Business Review, 2(10).

Abugamea, G. (2018). Determinants of Banking Sector Profitability: Empirical Evidence from Palestine. Retrieved from https://mpra.ub.uni-muenchen.de/89772/. MPRA Paper No. 89772, posted 30 Oct 2018 08:40 UTC

Adebayo, M., Adeyanju, D., \& Olabode, S. (2011). Liquidity Management and Commercial Banks' Profitability in Nigeria. Research Journal of Finance and Accounting, 2(7/8). Retrieved from http://www.iiste.org 
Agbada, A. O., \& Osuji, C.C. (2013). The Efficacy of Liquidity Management and Banking Performance in Nigeria. Review of Management and Business Research, 2(1).

Ahmed, E., Rahman, Z., \& Ahmed, R. I. (2006). Comperative analysis of loan recovery among nationalized, private and islamic commercial banks of Bangladesh. BRAC University Journal, 3(1), 35-52.

Alshatti, A. S. (2015). The effect of the Liquidity Management on the Profitability in the Jordian Commercial Banks. International Journal of Business and Management, 10(1).

Arif, A. \& Anees, A. N. (2012). Liquidity Risk and Performance of Banking System. Journal of Financial Regulation and Compliance, 20(2), 182-195, http://dx.doi.org/10.1108/13581981211218342

Aspachs, O., Nier, E. W., \& Tiesset, M. (2005). Liquidity, banking regulation and the macroeconomy: evidence on bank liquidity holdings from a panel of UK-resident banks, Bank of England, Working Paper, 2005.

AssafNeto, A. (2003). Finanças Corporativas e Valor. São Paulo: Atlas.

Basel Committee on Banking Supervision. (2008). Principles for Sound Liquidity management and Supervision, Basel, Switzerland: Bank for International Settlement.

Bassey, G. E. (2015). Bank Profitability and Liquidity Management: A case Study od Selected Nigerian Deposit Money Banks. International Journal of Economics, Commerce and Management, 3(4).

Bernanke, B. S. (2008). Liquidity Provision by the Federal Reserve, Risk Transfer Mechanisms and Financial Stability Workshop, Basel, Switzerland, on May 29, 2008.

Chandra, P. (2001). Financial Management. 7th edition, McGraw-Hill, New York, USA.

Central Bank of Barbados. (2008). Liquidity Risk Management Guideline. Bank Supervision Department, Central Bank of Barbados, Bridgetown.

Dodds, J. C. (1982). The Term Structure of Interest Rates: a Survey of the Theories and Empirical Evidence, Managerial Finance, 8(2), 22-31.

Datta, P. C., Ghosh, B. K., \& Tuhin, M. H. (2011). Financial Performance in Banking Sector in Bangladesh: A Comparative Study of Some Selected Private Commercial Banks. Department of Banking Faculty of Business Studies University of Dhaka. Journal of Banking \& Financial Services, 5(1), July 2011, 129-138.

Emmanuel, N. R. (1997). Commercial Banking in an Era of Deregulation. $3^{\text {rd }}$ Edition, Greenwood Publishing Group. 
Flannery, M. J., \& Rangan, P. (2008). What Caused the Bank Capital Build-up of the 1990s? Review of Finance, 12.

Goddard, J., Molyneux, P., \& Wilson, J.O.S. (2004). Dynamics of Growth and Profitability in Banking. Journal of Money, Credit and Banking, 36, 1069-1090.

Gujarati, D.N. (1995). Basic Econometrics. 3rd edition, McGraw-Hill,New York.

Gujarati, D.N., \& Sangeetha. (2008). Basic Econometrics. 4th edition, The Tata McGraw-Hill Companies, India.

Gup, B. E., \& Kolari, J. W. (2004). Commercial Banking: The Management of Risk. 3rd Edition, Wiley publication, New York, USA.

Hausman, J. A. (1978). Specification Tests in Econometrics. Econometrica: Journal of the Econometric Society, 46, 1251-1271.

Hirigoyen, G. (1985). Rentabilité et solvabilité. Direction et Gestion, 3, 13-26.

Hossain, M. J. (2000). A Study on the Performance of Public and Private Sector Commercial Banks in Bangladesh, an unpublished Ph.D Thesis, Institute of Bangladesh Studies, Rajshahi University, pp: IX-X.

Ramadan, I. Z., Kilani, Q. A., \& Kaddumi, T. A. (2011). DETERMINANTS OF BANK PROFITABILITY: EVIDANCE FROM JORDAN. International Journal of Academic Research, 3(4).

Jahangir, N., Shill, S., \& Haque, M. A. J. (2007). Examination of profitability in the context of Bangladesh banking industry. ABAC Journal, 27(2), 36-46.

Jenkinson, N. (2008). Strengthening regimes for controlling liquidity risk. Euro Money Conference on Liquidity and Funding Risk Management. Bank of England, London, p. 9.

Jose, M. L., Lancaste, C., \& Stevens, J. L. (1996). Corporate returns and cash conversion cycles. Journal of Economics and Finance, 20(1).

Kurawa, J. M., \& Abubakar, A. (2014). An evaluation of the impact of liquidity on the profitability of Nigerian banks. J Manag, 2(7), 1-7.

Kennedy, P. (2008). A Guide To Econometrics. $6^{\text {th }}$ edition, Wiley-Blackwell, New Jersey, USA.

Koch, T. W. (1992). Bank Management. $2^{\text {nd }}$ Edition, The Dryden Press, N.Y., pp.483-485.

Lartey, V., Antwi, S., \& Boadi, E. (2013). The Relationship between Liquidity and Profitability of Listed Banks in Ghana. International Journal of Business and Social Science, 4(3), 48-56. Retrieved from http://ijbssnet.com/journals 
Lucy, O.U., Nnenna, C.V., \& Nnenna, O. V. (2018). Effect of Liquidity on Financial Performance on Deposit Money Banks in Nigeria. Journal of Economics and Sustainable Development, 9(4), 19-28.

Mwangi, M., Muturi, W., \& Ombuki, C. (2015). The effects of Deposit to Asset ratio on the Financial Sustainability of Deposit taking Micro Finance Institutions in kenya. International Journal of Economics, Commerce and Management, 3(8).

Nwankwo, U. (1991). Economic Agenda for Nigeria. Centralist Production Ltd., Lagos, Nigeria.

Nzotta, S. M. (1997). Money, Banking and Finance: Theory and Practice. Owerri.

Obida, S. S., \& Owolabi, S. A. (2012). Liquidity Management and Corporate Profitability: Case Study of Selected Manufacturing Companies Listed on the Nigerian Stock Exchange. Business Management Dynamics, 2(2), 10-25.

Olarewaju, O. M., \& Adeyemi, O. K. (2015). Causal Relationship between Liquidity and Profitability of Nigerian Deposit Money Banks. International Journal of Academic Research in Accounting, Finance and Management Sciences, 5(2).

Osborn, M., Fuertes, A., \& Milne, A. (2012). Capital and Profitability in Banking: Evidence from US Banks.

Papa, V. (2012). Bank Earnings: Investors Should Pay Attention to Risk-Adjusted Performance. Market Integrity Insights, CFA Institute.

Rauch, C., Steffen, S., Hackethal, A., \& Tyrell, M. (2010). Determinants of bank liquidity creation.

Raza, A., Farhan, M., \& Akram, M. (2011). A comparison of financial performance in investment banking sector in Pakistan. International Journal of Business and Social Science, 2(9).

Repullo, T. M. (2003). Liquidity, risk taking and the lender of last resort, CEMFI, Madrid.

Siddique, M. (2004). Financial Sector Crisis in Japan: Impact of Non-performing loan on bank loan supply. Bank Parikrama: A journal of Banking and Finance, XXVIII \& XXIX, pp: $35-47$.

Sufian, F., \& Chong, R. R. (2008). Determinants of bank profitability in a developing economy: Empirical evidence from Philippines, Asian Academy of Management Journal of Accounting and Finance, 4(2), 91-112.

Tabari, N., Ahmadi, M., \& Emami, M. (2013). The Effect of Liquidity Risk on the Performance of Commercial Banks. International Research Journal of Applied and Basic Sciences, 4(6), 1624-1631. 
Wilner, B. (2000). Competitive Conditions in European Banking. Journal of Banking and Finance, 18.

Wooldridge, J. M. (2002). Econometric Analysis of Cross Sectional and Panel Data. Cambridge, MA: MIT Press.

Appendix-1 A: VIF Results

\section{APPENDICES}

\begin{tabular}{|c|c|c|}
\hline Variable & VIF value & Tolerance \\
\hline LQA/TAs & 3.92 & 0.26 \\
\hline LQA/TDs & 3.57 & 0.28 \\
\hline BSZ & 2.64 & 0.38 \\
\hline BDO/TAs & 2.28 & 0.44 \\
\hline TIC/TRW & 1.97 & 0.51 \\
\hline TDs/TAs & 1.83 & 0.55 \\
\hline MRI & 1.57 & 0.64 \\
\hline RRP/TLs & 1.53 & 0.65 \\
\hline TAs/SE & 1.47 & 0.68 \\
\hline NPL/GLA & 1.46 & 0.68 \\
\hline Mean VIF & $\mathbf{2 . 2 2}$ & \\
\hline
\end{tabular}

Notes: i) Data have been compiled by researcher

ii) Analysis mode: STATA (version 12.0)

\section{Appendix-1 B: White's Heteroskedasticity Test on ROE}

\begin{tabular}{|c|c|c|c|}
\hline Source & $\mathbf{C h i}^{\mathbf{2}}$ & df & p \\
\hline Heteroscedasticity & 66.00 & 43 & 0.4290 \\
\hline Skewness & 31.78 & 10 & 0.0004 \\
\hline Curtosis & 0.89 & 1 & 0.3460 \\
\hline Total & 76.67 & 54 & 0.0229 \\
\hline
\end{tabular}

Notes: i) Data have been compiled by researcher

ii) Analysis mode: STATA (version 12.0)

\section{Appendix-1C: White's Heteroskedasticity Test on ROCE}

\begin{tabular}{|c|c|c|c|}
\hline Source & $\mathbf{C h i}^{\mathbf{2}}$ & df & p \\
\hline Heteroscedasticity & 66.00 & 43 & 0.4290 \\
\hline Skewness & 8.99 & 10 & 0.5330 \\
\hline Curtosis & 1.50 & 1 & 0.2212 \\
\hline Total & 54.49 & 54 & 0.4559 \\
\hline
\end{tabular}

Notes: i) Data have been compiled by researcher

ii) Analysis mode: STATA (version 12.0) 


\section{Appendix-1D: Hausman Test on ROE}

\begin{tabular}{|c|c|c|c|c|}
\hline \multirow[t]{2}{*}{ ROE } & \multicolumn{4}{|l|}{ Coefficients } \\
\hline & $\begin{array}{c}\mathrm{b} \\
\text { Fixed }\end{array}$ & $\begin{array}{c}\text { B } \\
\text { Random }\end{array}$ & $\begin{array}{c}b-B \\
\text { Differences }\end{array}$ & $\begin{array}{c}\text { sqrt (diag(V_b- } \\
\text { V_B)) SE }\end{array}$ \\
\hline $\mathbf{X}_{1}:$ TAs/SE & -3.2444 & -3.2398 & -.0047 & .1409 \\
\hline $\mathbf{X}_{2}:$ TIC/TRW & 5.8043 & 6.0589 & -.2546 & .2472 \\
\hline $\mathbf{X}_{3}:$ LQA/TAs & 1.9815 & .1159 & 1.8656 & 1.1810 \\
\hline $\mathbf{X}_{4}:$ RRP/TLs & .2120 & -.4326 & .6446 & 1.7642 \\
\hline $\mathbf{X}_{5}:$ LQA/TD & .3758 & -.5235 & .8993 & .6923 \\
\hline $\mathbf{X}_{\mathbf{6}}: \mathrm{BDO} / \mathrm{TAs}$ & -6.4881 & -3.5083 & -2.9798 & 2.2446 \\
\hline $\mathbf{X}_{7}:$ TDs/TAs & 3.5190 & 3.1273 & .3917 & .4181 \\
\hline $\mathbf{X}_{8}:$ NPL/GLA & .6512 & .5269 & .1242 & .8021 \\
\hline X9: MRI & -2.9912 & -2.5484 & -.4428 & .8258 \\
\hline $\mathbf{X}_{10}:$ BSZ & -102.4167 & -49.2252 & -53.1915 & 31.7284 \\
\hline
\end{tabular}

Notes: i) Data have been compiled by the researcher

ii) Analysis Mode: STATA (version 12.0)

iii) $\mathrm{b}=$ consistent under Ho and Ha; obtained from xtreg

$\mathrm{B}=$ inconsistent under $\mathrm{Ha}$, efficient under Ho; obtained from xtreg

iv) Test: Ho: difference in coefficients not systematic

Chi2 (3) $=(b-B)^{1}\left[\left(V \_b-V \_B\right)^{\wedge}(-1)\right](b-B)=3.02$

Prob $>$ chi $2=0.3881$

\section{Appendix-1E: Hausman Test on ROCE}

\begin{tabular}{|c|c|c|c|c|}
\hline \multirow[t]{2}{*}{ ROCE } & \multicolumn{4}{|l|}{ Coefficients } \\
\hline & $\begin{array}{c}\mathrm{b} \\
\text { Fixed }\end{array}$ & $\begin{array}{c}\text { B } \\
\text { Random }\end{array}$ & $\begin{array}{c}\text { b-B } \\
\text { Differences }\end{array}$ & $\begin{array}{c}\text { sqrt (diag(V_b-V_B })) \\
\text { SE }\end{array}$ \\
\hline $\mathbf{X}_{\mathbf{1}}:$ TAs/SE & -.0784 & -.0787 & .0002 & .0153 \\
\hline $\mathbf{X}_{2}:$ TIC/TRW & .0804 & .0709 & .0095 & .0269 \\
\hline $\mathbf{X}_{3}$ : LQA/TAs & -.1229 & -.1708 & .0480 & .1283 \\
\hline $\mathbf{X}_{4}:$ RRP/TLs & .0717 & .0154 & .0563 & .1917 \\
\hline $\mathbf{X}_{5}:$ LQA/TD & .1267 & .1532 & -.0264 & .0752 \\
\hline $\mathbf{X}_{6}:$ BDO/TAs & .1107 & -.0177 & .1284 & .2439 \\
\hline $\mathbf{X}_{7}:$ TDs/TAs & -.0016 & -.0320 & .0304 & .0454 \\
\hline Xs: NPL/GLA & .0108 & .0333 & -.0225 & .0872 \\
\hline $\mathbf{X}_{9}:$ MRI & .3137 & .3275 & -.0138 & .0897 \\
\hline $\mathbf{X}_{10}:$ BSZ & -4.3824 & -4.2098 & -.1726 & 3.4475 \\
\hline
\end{tabular}

Notes: i) Data have been compiled by the researcher

ii) Analysis Mode: STATA (version 12.0)

iii) $\mathrm{b}=$ consistent under Ho and Ha; obtained from xtreg

$\mathrm{B}=$ inconsistent under $\mathrm{Ha}$, efficient under Ho; obtained from xtreg

iv) Test: Ho: difference in coefficients not systematic

Chi2 (3) $=(b-B)^{1}\left[\left(V \_b-V \_B\right)^{\wedge}(-1)\right](b-B)=0.80$

$$
\text { Prob }>\text { chi } 2=0.8494
$$




\begin{abstract}
AUTHOR CONTRIBUTIONS
Conceptualization: Nazneen Jahan Chaudhury

Data curation: Nazneen Jahan Chaudhury

Formal analysis: Nazneen Jahan Chaudhury

Funding Acquisition: Nazneen Jahan Chaudhury

Project Administration: Nazneen Jahan Chaudhury

Software: Nazneen Jahan Chaudhury

Validation: Nazneen Jahan Chaudhury

Writing - Original Draft: Nazneen Jahan Chaudhury

Writing - Review \& Editing: Nazneen Jahan Chaudhury

\section{CONFLICT OF INTEREST STATEMENT}

The authors declare that they have no competing interests.

\title{
COPYRIGHTS
}

Copyright for this article is retained by the author(s), with first publication rights granted to the journal. This is an open-access article distributed under the terms and conditions of the Creative Commons Attribution license (https://creativecommons.org/licenses/by/4.0). 